母子世帯の住宅確保の実態と問題に関する研究

\title{
A STUDY ON INSECURE HABITATION OF SINGLE MOTHER HOUSEHOLDS
}

暮西りサ*, 塩崎賢明**, 堀田 祐三子***

Lisa KUZUNISHI, Yoshimitsu SHIOZAKI and Yumiko HORITA

This study aims to understand housing situation of Single Mother Households who are divorced or widowed in Japan.

Recently, the greater rate of divorce or separation caused by changes in lifestyles and social status for women have been contributing to the growing number of Single Mother Households. However, these families are facing difficulties in seeking to be oconomically and socially independent. As their income is just a fraction of the general households, under the profit-oriented housing provision, it is hard for many of them to own or rent housing because housing expenses for housing are still much of a burden for single mother households to bear.

Keywords : Single Mother Household, Divorce, Separation, Lifestyle, Economically and Socially independence 母子家庭、離婚、別居、ライフスタイル、経済的・社会的自立

\section{1. はじめに}

\section{1-1. 研究の背贯と目的}

母子世帯の多くは、母子世帯になることを機に転居する傾向が高い ことが明らかになっている。しかしながら、母子世帯にとって、転居し、住 宅を確保することは、経済的問題、子育ての問題等も含めて障害が多い と推測される。

そこで、本研究では母子世帯の住宅確保の実態とその問題について 明らかにすることを目的とする。

母子世帯の住宅確保を支援する公的施策には、母子生活支援施設の

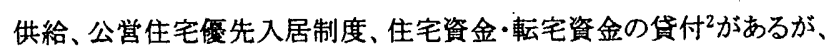
これらは、母子世帯のニーズに合致するものとなっていないのが現状で ある。

従って、母子世帯の住宅確保の実態を明らかにすることは、彼女らの ニーズにあった住宅確保のための支援方策を構筑する上で重要な知見 をもたらすと考えられる。

母子世帯の住宅事情に関する既存研究には、田端（1993）、杉本 （1997）、由井 (2003）があるが、これらは、既存の官庁統計利 用し、母子世帯の住宅所有関係の特徽を述べるに止まっている。

この他、母子生活支援施設の入居者を対象とした研究（林・1992 年、湯沢・1997 年、松原・1999 年、由井・2000）はあるが、母子 世帯の住宅確保がいかに困難であるかを明らかにした研究は皆無 である。

\section{1-2. 研究の方法}

社会福祉法人大阪府母子寨婦福祉連合会 4 (舟子連)の協力を得て、 2004 年 1 月から 2 月にかけて郵送アンケート調查を行った。

对象世帯の選定にあたっては、母子連の会員 4,600世帯5うち、 600 世带を無作為抽出した。

アンケート配布数は 600 件、回収数は 240 件であり、回収率は $40.0 \%$ あった。

\section{2. 回答世带の特性}

\section{2-1. 基本的特性}

\section{1）母子世费になった理由と本人の年耣}

回答世带 240 世帯のうち、死別母子世帯は、15.4\%（37 世帯）、 生別母子世帯は、84.6\%(203 世帯) であり、纴倒的に生別母子世 帯の割合が高い（表 1）。

生別母子世帯の内訳を見ると、9 割以上（190 世帯）が離別母子 世帯となっている。

衰 1 母世楆になった理由

\begin{tabular}{c|c|ccc|c}
\hline \multirow{2}{*}{ 死別 } & \multirow{4}{*}{ 生別 } & \multicolumn{3}{|c|}{ 生別内訳 } & 死別·生別 \\
\cline { 3 - 6 } & & 離別 & 未婚·非㛭 & ₹の他 & 合計 \\
\hline 37 & 203 & 190 & 9 & 4 & 240 \\
$15.4 \%$ & $84.6 \%$ & $93.6 \%$ & $4.4 \%$ & $2.0 \%$ & $100 \%$ \\
\hline
\end{tabular}

* 神戸大学自然科学研究科 博士後期課程

***神百大学:工学部建設学科 教授・工博

**** 神戸大学自然科学研究科 助手. 工博
Graduate Student, Graduate School of Science and Technology, Kobe University Prof., Dept. of Architecture, Kobe University, Dr. Eng.

Research Fellow, Graduate School of Science and Technology, Kobe University, Dr. Eng. 
続いて回答者自身の年齢は、30 代が最も多く $55.8 \%$ (134 人)、次 いで 40 代が $36.7 \%$ (88 人) である（表 2）。

\begin{tabular}{cccc|c} 
襄 2 & 本人の年䖝 \\
\hline 201 代 & 30 代 & 40 代 & 50 代 & 合㖕 \\
\hline 11 & 134 & 88 & 7 & 240 \\
$4.60 \%$ & $55.80 \%$ & $36.70 \%$ & $2.90 \%$ & $100 \%$ \\
\hline
\end{tabular}

\section{2）子供の状況}

子供の数は、 2 人の割合が最も高く $46.7 \%$ (112 世带)、続いて、 1 人が $28.8 \%$ (69 世帯) 3 人が $20.0 \%$ （48 世带）となっている（表 3) 。

\section{裹 3 于供の人数}

\begin{tabular}{ccccc|c}
\hline $1 \lambda$ & $2 \lambda$ & $3 \lambda$ & $4 \lambda$ & $5 \lambda$ & 合阡 \\
\hline 69 & 112 & 48 & 9 & 2 & 240 \\
$28.8 \%$ & $46.7 \%$ & $20.0 \%$ & $3.8 \%$ & $0.8 \%$ & $100 \%$ \\
\hline
\end{tabular}

次に、現在の子供の就学状況について見ると、小学生の子供のい る世帯の割合 $(70.4 \%)$ が圧倒的に高く、続いて中学生の子供のい る世带の割合 (31.7\%) が高い（表 4)。

母子世帇になった当時では、8 割以上が就学前の子供を抱えてい る。続いて割合が高いのが、小学生の子供を持つ世帯 $(33.3 \%)$ と なっている。

\section{哀 4 子供の就粪状況（被数回答）}

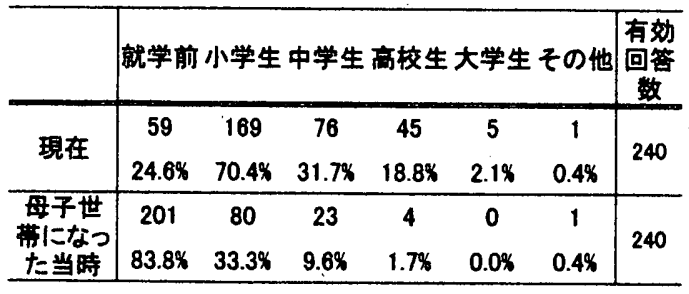

\section{3）舟子世带になってからの経過年数}

母子世帯になってからの経過年数は、6〜 10 年 (30.8\%) の割合が 最も高く、続いて 6〜10 年 $(30.8 \%)$ の割合が高い（表 5)。

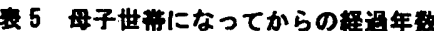

\begin{tabular}{cccccc|c}
\hline 1 年末满 & $1 \sim 3$ 年 & $3 \sim 6$ 年 & $6 \sim 10$ 年 & 10 年以上 & 不明 & 含㖕 \\
\hline 13 & 26 & 74 & 81 & 43 & 3 & 240 \\
$5.4 \%$ & $10.8 \%$ & $30.8 \%$ & $33.8 \%$ & $17.8 \%$ & $1.3 \%$ & $100 \%$ \\
\hline
\end{tabular}

\section{4) 仕毠の状况}

図 1 は、「母子世带になる前」、「子世帯になった直後」「現在」の 母子世帯の就業状況を示したものである。

「母子世带になる前」から「現在」にかけて、有業の割合が上年 している。

「母子世帯になった直後」では、回答者本人が 1 人で家計を支えて いかなければならないため、有業の割合は増加するが、その就労形 熊は、儥金の低いパート労倒の割合 $(70.2 \%)$ が極めて高くなって いる(表 5)。
これは、彼女らが「母子世帯になる前」に就業していない、ある いは就業していてもパートタイムの仕事であったために、正社貣の 職につくにあたっての十分なキャリアがないことが一因ではない かと推察される。また、「母子世帯になった直後」では、就学前の 子供を抱えていた割合が極めて高く、育児のためにフルタイムで働 けず、やむを得ずパート労倒を選択せね估ならないのではないかと 考えられる。

これらのことは、「母世帯になった直後」から「現在」にかけ て、パートの割合が低下し、正社員の割合が上昇していることから も裏付けられる。

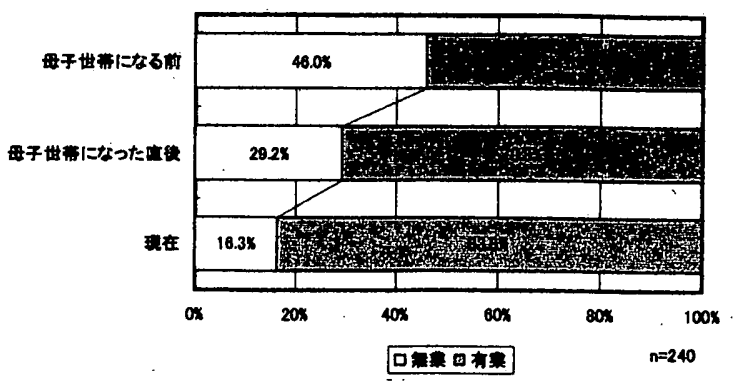



5 就学形繁の内㧽 $(P<0.001)$

\begin{tabular}{|c|c|c|c|c|c|c|}
\hline & 正社只 & ハiート & 自虽菜等 & その他 & 不明 & 合部 \\
\hline $\begin{array}{c}\text { 母子萧にな } \\
\text { 前 }\end{array}$ & $\begin{array}{c}28 \\
21.4 \%\end{array}$ & $\begin{array}{c}82 \\
62.6 \%\end{array}$ & $\begin{array}{c}18 \\
13.7 \% \\
\end{array}$ & $\begin{array}{c}0 \% \\
0.0 \%\end{array}$ & $\begin{array}{c}3 \\
2.3 \% \\
\end{array}$ & $\begin{array}{c}131 \\
100 \pi\end{array}$ \\
\hline $\begin{array}{l}\text { 母子世带に } \\
\text { なつた声後 }\end{array}$ & $\begin{array}{c}36 \\
21.18 \\
\end{array}$ & $\begin{array}{c}120 \\
70.2 \% \\
\end{array}$ & $\begin{array}{c}9 \\
5.3 \%\end{array}$ & $\begin{array}{c}2 \\
1.2 \%\end{array}$ & $\begin{array}{c}4 \\
2.3 x \\
\end{array}$ & $\begin{array}{c}171 \\
100 \% \\
\end{array}$ \\
\hline 現在 & $\begin{array}{c}69 \\
34.3 \% \\
\end{array}$ & $\begin{array}{c}115 \\
57.2 \% \\
\end{array}$ & $\begin{array}{c}11 \\
5.5 \%\end{array}$ & $\begin{array}{c}6 \\
3.0 \% \\
\end{array}$ & $\begin{array}{c}0 \\
0.0 \%\end{array}$ & $\begin{array}{c}201 \\
100 \%\end{array}$ \\
\hline
\end{tabular}

\section{3. 坛居の状況とその受因}

\section{3-1. 死別・生別に見る転居状況の相远}

母子世帯になることを機に転居する世带は全体の73.8\%であり、 転居しなかった世帯（26.2\%）を大きく上回っている（図 2)。

転居の有無は、母子世帶になった要因によって大きく異なる。

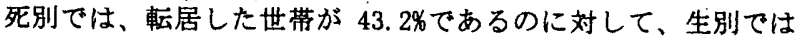
$79.6 \%$ である。

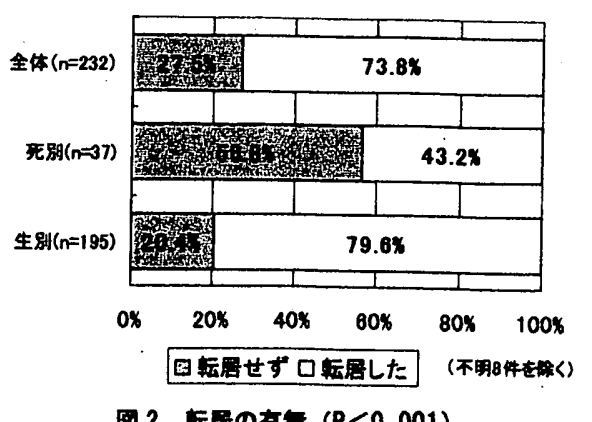

これを、結婚時に住んでいた住宅の所有関係別に見ると、以下の ような特徽が見られる(表 6)。

第1に、結婚時の住宅が持家であるか、もしくは、同居していた 
死別母子世帯は、借家に居住する世帯と比較して、転居せず、その まま定住する傾向が高い。一方、生別母子世帯では、持家に住んで いても、同居をしていても、転居をしない割合は、それぞれ $11.8 \%$ 、 $21.9 \%$ と低くなっている。

第 2 に、生別母子世帯では、公営住宅に居住していた世带以外は、 全て「転居した」とする割合が高くなっている。

次節では、結婚時に居住していた住宅の所有関係によって、こう した差が生じる要因について分析を行う。

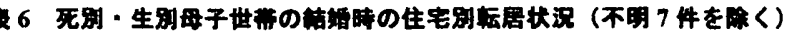

\begin{tabular}{|c|c|c|c|c|c|c|c|c|}
\hline & \multicolumn{3}{|c|}{ 死別 } & \multicolumn{3}{|c|}{ 生别 } & \multirow[b]{2}{*}{ 㛀含尌 } \\
\hline & & $\begin{array}{c}\text { 軦居せ } \\
\text { す }\end{array}$ & $\begin{array}{c}\text { 転居L } \\
t=\end{array}$ & 含尌 & 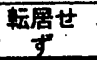 & 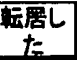 & 合計 & \\
\hline \multirow{8}{*}{ 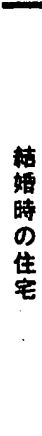 } & 持源 & $\begin{array}{c}11 \\
84.6 \% \\
\end{array}$ & $\begin{array}{c}2 \\
15.4 \% \\
\end{array}$ & $\begin{array}{c}13 \\
100 \% \\
\end{array}$ & $\begin{array}{c}6 \\
11.8 \% \\
\end{array}$ & $\begin{array}{c}45 \\
88.2 \% \\
\end{array}$ & $\begin{array}{c}51 \\
100 \% \\
\end{array}$ & 64 \\
\hline & 公兴住宅 & $\begin{array}{c}0 \\
0.0 \%\end{array}$ & $\begin{array}{c}2 \\
100 \%\end{array}$ & $\begin{array}{c}2 \\
100 \%\end{array}$ & $\begin{array}{c}10 \\
62.5 \%\end{array}$ & $\begin{array}{c}6 \\
37.5 \%\end{array}$ & $\begin{array}{c}16 \\
100 \%\end{array}$ & 18 \\
\hline & 公団·公社 & $\begin{array}{c}1 \\
100 \% \\
\end{array}$ & $\begin{array}{c}0 \\
0.0 \%\end{array}$ & $\begin{array}{c}1 \\
100 x \\
\end{array}$ & $\begin{array}{c}2 \\
14.3 \%\end{array}$ & $\begin{array}{c}12 \\
85.7 \% \\
\end{array}$ & $\begin{array}{c}14 \\
100 \% \\
\end{array}$ & 15 \\
\hline & 社宅 & $\begin{array}{c}0 \\
0.0 \%\end{array}$ & $\begin{array}{c}2 \\
100 \% \\
\end{array}$ & $\begin{array}{c}2 \\
100 \% \\
\end{array}$ & $\begin{array}{c}0 \\
0.0 \% \\
\end{array}$ & $\begin{array}{c}8 \\
100 \% \\
\end{array}$ & $\begin{array}{c}8 \\
100 x \\
\end{array}$ & 10 \\
\hline & 民用借家 & $\begin{array}{c}2 \\
25.0 \% \\
\end{array}$ & $\begin{array}{c}6 \\
75.0 \% \\
\end{array}$ & $\begin{array}{c}8 \\
100 \% \\
\end{array}$ & $\begin{array}{c}14 \\
20.0 \% \\
\end{array}$ & $\begin{array}{c}56 \\
80.0 \% \\
\end{array}$ & $\begin{array}{c}70 \\
100 \%\end{array}$ & 78 \\
\hline & 周喏 & $\begin{array}{c}7 \\
70.0 \%\end{array}$ & $\begin{array}{c}3 \\
30.0 \%\end{array}$ & $\begin{array}{c}10 \\
100 \% \\
\end{array}$ & $\begin{array}{c}7 \\
21.9 \%\end{array}$ & $\begin{array}{c}25 \\
78.1 \%\end{array}$ & $\begin{array}{c}32 \\
100 \%\end{array}$ & 42 \\
\hline & その他 & $\begin{array}{c}0 \\
0 \%\end{array}$ & $\begin{array}{c}1 \\
100 \% \\
\end{array}$ & $\begin{array}{c}1 \\
100 \% \\
\end{array}$ & $\begin{array}{c}0 \\
0 \%\end{array}$ & $\begin{array}{c}1 \\
100 \% \\
\end{array}$ & $\begin{array}{c}1 \\
100 \%\end{array}$ & 2 \\
\hline & 不明 & $\begin{array}{c}0 \\
\text { ox }\end{array}$ & $\begin{array}{c}0 \\
0 \%\end{array}$ & $\begin{array}{c}0 \\
\text { Ox }\end{array}$ & $\begin{array}{c}1 \\
25\end{array}$ & $\begin{array}{c}3 \\
75 \\
\end{array}$ & $\begin{array}{c}4 \\
100 \%\end{array}$ & 4 \\
\hline
\end{tabular}

$(P<0.01)$

\section{3-2. 伝居の要因}

\section{1）持家}

表 7は、結婚時に持家に居住していた世帯の持家の名義について 示したものである。

結婚時の持家の名義は、元夫である割合が最も高く、その割合は、

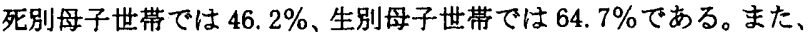
本人名義である割合は、生別・死別母子世帯ともに低い。

\begin{tabular}{|c|c|c|c|c|c|c|c|c|c|}
\hline & 本人 & 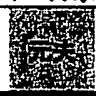 & $\begin{array}{l}\text { 本人と } \\
\text { 元夫 }\end{array}$ & 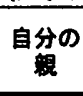 & 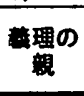 & 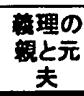 & その他 & 不明 & 合偖 \\
\hline 死別 & $\begin{array}{c}1 \\
7.7 \%\end{array}$ & 64 & $\begin{array}{c}0 \\
0.0 \%\end{array}$ & $\begin{array}{c}1 \\
7.7 \%\end{array}$ & $\begin{array}{c}1 \\
7.7 x\end{array}$ & $\begin{array}{c}1 \\
7.7 \%\end{array}$ & $\begin{array}{c}1 \\
7.7 x\end{array}$ & $\begin{array}{c}2 \\
15.4 x\end{array}$ & $\begin{array}{c}13 \\
100 \% \\
\end{array}$ \\
\hline 生別 & $\begin{array}{c}2 \\
3.7 x\end{array}$ & 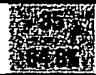 & $\begin{array}{c}3 \\
5.6 \%\end{array}$ & $\begin{array}{c}7 \\
13.0 \%\end{array}$ & $\begin{array}{c}1 \\
1.9 \%\end{array}$ & $\begin{array}{c}0 \\
0.0 \%\end{array}$ & $\begin{array}{c}3 \\
5.6 \%\end{array}$ & $\begin{array}{c}3 \\
5.8 \%\end{array}$ & $\begin{array}{c}54 \\
100 \%\end{array}$ \\
\hline 合鲇 & $\begin{array}{c}3 \\
4.5 \%\end{array}$ & 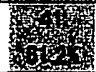 & $\begin{array}{c}4 \\
6.0 \%\end{array}$ & $\begin{array}{c}7 \\
10.4 \%\end{array}$ & $\begin{array}{c}2 \\
3.0 \%\end{array}$ & $\begin{array}{c}1 \\
1.5 \%\end{array}$ & $\begin{array}{c}4 \\
6.0 \%\end{array}$ & $\begin{array}{c}5 \\
7.5 \%\end{array}$ & $\begin{array}{c}67 \\
100 \%\end{array}$ \\
\hline
\end{tabular}

そこで、家の名義と転居の関係をみるために、結婚時における持 家の名義別に転居の状況を見る（表 8）。

死別母子世帯では、元夫の名義であっても、その住宅を相続し、 そのまま住み綍ける割合 $(83.3 \%)$ が高い。

他方で、生別母子世帯では、持家の名義が元夫であった場合は、 97.0\%が転居している。しかしながら、本人の名義や元夫との共同 名義であった場合でも、その全てが転居している。

このことから、結婚時の住宅が持家であった生別母子世帯の転居 の割合が高いのは、（1）結婚時の持家の名義が元夫である事も一因 であるが、それ以外に、(2) 離婚時の財産分与の関保”や（3）ロー
ン支払いが残っている場合、その支払いが困難倳になるなどの理由か らではないかと考えられる。

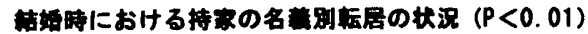

\begin{tabular}{|c|c|c|c|c|c|c|c|}
\hline & \multicolumn{3}{|c|}{ 死副 } & \multicolumn{3}{|c|}{ 生別 } & \multirow[b]{2}{*}{ 絡合尌 } \\
\hline & $\begin{array}{c}\text { 蛭居L } \\
t=\end{array}$ & ず & 合㣌 & $\begin{array}{c}\text { F居L } \\
t\end{array}$ & 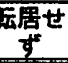 & 合计 & \\
\hline 本人 & $\begin{array}{c}0 \\
0 \%\end{array}$ & $\begin{array}{c}1 \\
100 \%\end{array}$ & $\begin{array}{c}1 \\
100 \%\end{array}$ & $\begin{array}{c}2 \\
100 \%\end{array}$ & $\begin{array}{c}0 \\
0 \%\end{array}$ & $\begin{array}{c}2 \\
100 \%\end{array}$ & 3 \\
\hline 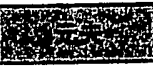 & 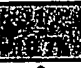 & Fod & fort & $8 \%$ & Sid & 9 & 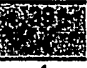 \\
\hline 本人の犊 & $\begin{array}{c}0 \\
0 \%\end{array}$ & $\begin{array}{c}1 \\
100 \%\end{array}$ & $\begin{array}{c}1 \\
100 \%\end{array}$ & $\begin{array}{c}0 \\
0 \%\end{array}$ & $\begin{array}{c}3 \\
100 \%\end{array}$ & $\begin{array}{c}3 \\
100 \%\end{array}$ & 4 \\
\hline 本人と元夫 & $\begin{array}{c}0 \\
0 \%\end{array}$ & $\begin{array}{c}0 \\
0 \% \\
\end{array}$ & $\begin{array}{c}0 \\
0 \% \\
\end{array}$ & $\begin{array}{c}7 \\
100 \% \\
\end{array}$ & $\begin{array}{c}0 \\
0 \% \\
\end{array}$ & $\begin{array}{c}7 \\
100 \% \\
\end{array}$ & 7 \\
\hline 理积 & $\begin{array}{c}1 \\
100 \% \\
\end{array}$ & $\begin{array}{l}0 \\
0 \%\end{array}$ & $\begin{array}{c}1 \\
100 \% \\
\end{array}$ & $\begin{array}{c}1 \\
100 \% \\
\end{array}$ & $\begin{array}{c}0 \\
0 \%\end{array}$ & $\begin{array}{c}1 \\
100 \%\end{array}$ & 2 \\
\hline 藮理船と元夫 & $\begin{array}{l}0 \\
0 \%\end{array}$ & $\begin{array}{c}1 \\
100 \%\end{array}$ & $\begin{array}{c}1 \\
100 \% \\
\end{array}$ & $\begin{array}{c}0 \\
0 \%\end{array}$ & $\begin{array}{c}0 \\
0 \% \\
\end{array}$ & $\begin{array}{c}0 \\
0 \%\end{array}$ & 1 \\
\hline その他 & $\begin{array}{l}0 \\
0 \%\end{array}$ & $\begin{array}{c}1 \\
100 \% \\
\end{array}$ & $\begin{array}{c}1 \\
100 \% \\
\end{array}$ & $\begin{array}{c}3 \\
100 \% \\
\end{array}$ & $\begin{array}{c}0 \\
0 \% \\
\end{array}$ & $\begin{array}{c}3 \\
100 \% \\
\end{array}$ & 4 \\
\hline 不明 & $\begin{array}{c}0 \\
0 \%\end{array}$ & $\begin{array}{c}2 \\
100 \%\end{array}$ & $\begin{array}{c}2 \\
100 \%\end{array}$ & $\begin{array}{c}0 \\
0 \%\end{array}$ & $\begin{array}{c}2 \\
100 \% \\
\end{array}$ & $\begin{array}{c}2 \\
100 \%\end{array}$ & 4 \\
\hline 合针 & $\begin{array}{c}2 \\
15.4 \%\end{array}$ & $\begin{array}{c}11 \\
84.6 \% \\
\end{array}$ & $\begin{array}{c}13 \\
100.0 \% \\
\end{array}$ & $\begin{array}{c}45 \\
88.2 \% \\
\end{array}$ & $\begin{array}{c}6 \\
11.8 \% \\
\end{array}$ & $\begin{array}{c}51 \\
100 \% \\
\end{array}$ & 64 \\
\hline
\end{tabular}

\section{2) 同居}

表 9 は、結婚時の同居先と転居の有無を示したものである。 生別母子世帯では、元夫の実家に同居していた世帯の全てが転居 しており、更に、同居先が本人の実家であってもその半分が転居し ている。

自分の実家であるにも関わらず、転居せざるを得なくなる要因に ついて、明解に言及できないが、恐らく、離婚によって、実家との 関係が悪くなる゚、あるいは、近隣の目が気になる ${ }^{10}$ 等の理由からで はないかと考えられる。

他方で、死別母子世帯では、同居先が本人の実家である場合はそ の全てが転居しておらず、また、同居先が元夫の実家であっても転 居しなかったとする割合が $57.1 \%$ となっている。

これらのため、結婚時に同居していた生別母子世帯は、死別母子 世帯と比較して転居する割合が高くなっているのである。

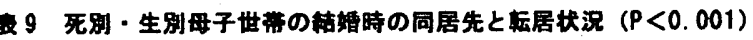

\begin{tabular}{|c|c|c|c|c|c|c|c|}
\hline \multirow[t]{2}{*}{. } & \multicolumn{3}{|c|}{ 死別 } & \multicolumn{3}{|c|}{ 生別 } & \multirow[b]{2}{*}{ 絡合㖕 } \\
\hline & $\begin{array}{l}\text { 枟居L } \\
t\end{array}$ & $\begin{array}{c}\text { 元居せ } \\
\text { ず }\end{array}$ & 合部 & $\begin{array}{c}\text { 転居L } \\
t=\end{array}$ & $\begin{array}{l}\text { 云居せ } \\
\text { ず }\end{array}$ & 合部 & \\
\hline 自分の犊㝗 & $\begin{array}{c}0 \\
0 \%\end{array}$ & $\begin{array}{c}3 \\
100 \%\end{array}$ & $\begin{array}{c}3 \\
100 \%\end{array}$ & $\begin{array}{c}7 \\
50.0 \%\end{array}$ & $\begin{array}{c}7 \\
50.0 \%\end{array}$ & $\begin{array}{c}14 \\
100 \%\end{array}$ & .17 \\
\hline 元夫の实家 & $\begin{array}{c}3 \\
42.9 \%\end{array}$ & $\begin{array}{c}4 \\
57.1 \%\end{array}$ & $\begin{array}{c}7 \\
100 \% \\
\end{array}$ & $\begin{array}{c}12 \\
100 \% \\
\end{array}$ & $\begin{array}{c}0 \\
0 \%\end{array}$ & $\begin{array}{c}12 \\
100 \% \\
\end{array}$ & 19 \\
\hline $\begin{array}{c}\text { その他の親 } \\
\text { 類宅 }\end{array}$ & $\begin{array}{c}0 \\
0 \%\end{array}$ & $\begin{array}{c}0 \\
0 \%\end{array}$ & $\begin{array}{c}0 \\
0 \%\end{array}$ & $\begin{array}{c}6 \\
100 \%\end{array}$ & $\begin{array}{c}0 \\
0 \%\end{array}$ & $\begin{array}{c}6 \\
100 \% \\
\end{array}$ & 6 \\
\hline 合斯 & $\begin{array}{c}3 \\
30.0 \%\end{array}$ & $\begin{array}{c}7 \\
70.0 \%\end{array}$ & $\begin{array}{c}10 \\
100 \%\end{array}$ & $\begin{array}{c}25 \\
78.1 \% \\
\end{array}$ & $\begin{array}{c}7 \\
21.9 \% \\
\end{array}$ & $\begin{array}{c}32 \\
100 \% \\
\end{array}$ & 42 \\
\hline
\end{tabular}

\section{3）借家}

結婚時に民間借家に居住していた世带については、死別・生別と もに転居したと回答している世帯が7割を超えている。

生別に限って見ると、同じ借家であっても、公営住宅に居住して いた世帯は転居する割合が低い。これは、民間借家では家賃が高額 である等、そこに止まるメリットがそれ程大きくないのに対して、 公営住宅では低家貨である上に居住水準がある程度確保されると 
いう点でメリットが大きい"たためではないかと推測される。

また、結婚時に社宅に居住していた世帯については、死別、生別 に限らず、全ての世帯が転居している。

これは、結婚時の主たる働き手が元夫であり、その会社の住宅に 居住していたため、転居せざるを得なくなるためであろう。

\section{4. 芸居時期・枟居先・居住期间}

\section{4-1. 枟居時期}

母子世帯になってから転居した 172 世帯の転居の時期について見 ると、「母子世帯になると同時に転居」した世帯が $43.6 \%$ と最も高 く、綍いて、「子茦になってしばらくして転居」した世帯が 31.4\%である。また「母子世帯になる前に転居」つまり、離婚が成 立する前に転居した世帯は $25.0 \%$ であった（表 10)。この「母子世 带になる前に転居」した要因は様々であると考えられるが、その中

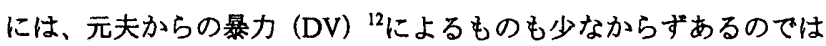
ないかと推測される。

転居時期と転居先をクロスして見ると、「母子世帯になる前に転 居」した世带は、親類・知人宅に身を奇せる割合が最も高く $(60.5 \%)$ 繶いて、民間借家に移る割合（23.3\%）が高い。

「母子世帯になると同時に転居」した世帯は、民間借家に転居する 割合が $49.3 \%$ と最も高くなっているが、依然として親類・知人宅に 身を寄せる世帯も $42.7 \%$ 存在する。

「母子世帯になってしばらくして転居」した世帯では、民間借家 に転居する割合 $(37.0 \%)$ が最も高くなっているものの、「母子世带 になる前に転居」や「母子世帯になると同時に転居」した世帯と比 較して、民閒借家及び親類・知人宅に転居する割合が低下し、公営 住宅に転居する割合（22.2\%）が增加している。

㿪 10 枟居時期と输居先 $(P<0.001)$

\begin{tabular}{|c|c|c|c|c|c|c|c|c|c|c|}
\hline & \multicolumn{8}{|c|}{ 动唐先 } & \multirow[b]{2}{*}{ 合辢 } & \multirow[b]{2}{*}{ 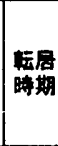 } \\
\hline & 持家 & $\begin{array}{l}\text { 公总 } \\
\text { 住宅 }\end{array}$ & 公团 & 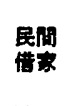 &  & $\begin{array}{l}\text { 母子 } \\
\text { 生活 } \\
\text { 支擐 } \\
\text { 施睡 }\end{array}$ & $\begin{array}{c}\text { ₹の } \\
\text { 地 }\end{array}$ & 不间 & & \\
\hline 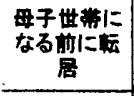 & $\begin{array}{c}3 \\
7.0 \% \\
\end{array}$ & $\begin{array}{r}1 \\
2.3 x \\
\end{array}$ & $\begin{array}{r}1 \\
2.3 \% \\
\end{array}$ & $\begin{array}{r}10 \\
23.3 \% \\
\end{array}$ & $60.5 \%$ & $\begin{array}{c}1 \\
2.3 \% \\
\end{array}$ & $\begin{array}{c}0 \\
0.0 \% \\
\end{array}$ & $\begin{array}{r}1 \\
2.3 \% \\
\end{array}$ & $\begin{array}{c}43 \\
100 \% \\
\end{array}$ & $\begin{array}{r}43 \\
25.09 \\
\end{array}$ \\
\hline $\begin{array}{c}\text { 母子世蓝に } \\
\text { なると同時に } \\
\text { 忶居 }\end{array}$ & $\begin{array}{c}2 \\
2.7 \% \\
\end{array}$ & $\begin{array}{c}1 \\
1.3 x \\
\end{array}$ & $\begin{array}{c}1 \\
1.3 \%\end{array}$ & $\begin{array}{c}37 \\
49.3 \%\end{array}$ & $\begin{array}{c}32 \\
42.7 \% \\
\end{array}$ & $\begin{array}{c}1 \\
1.3 \%\end{array}$ & $\begin{array}{c}1 \\
1.3 \%\end{array}$ & $\begin{array}{c}0 \\
0.0 \% \\
\end{array}$ & $\begin{array}{c}75 \\
100 \% \\
\end{array}$ & $\begin{array}{r}75 \\
43.69 \\
\end{array}$ \\
\hline 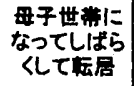 & $\begin{array}{c}7 \\
13.0 \%\end{array}$ & $\begin{array}{c}12 \\
22.2 x\end{array}$ & $\begin{array}{c}0 \\
0.0 \%\end{array}$ & $\begin{array}{c}20 \\
37.0 \%\end{array}$ & $\begin{array}{c}11 \\
20.4 \%\end{array}$ & $\begin{array}{c}2 \\
3.7 \%\end{array}$ & $\begin{array}{c}1 \\
1.9 \%\end{array}$ & $\begin{array}{c}1 \\
1.9 \%\end{array}$ & $\begin{array}{c}54 \\
100 \%\end{array}$ & $\begin{array}{r}54 \\
31.49\end{array}$ \\
\hline 合针 & $\begin{array}{r}12 \\
7.0 \%\end{array}$ & $\begin{array}{r}14 \\
8.1 \%\end{array}$ & $\begin{array}{c}2 \\
1.2 \%\end{array}$ & $\begin{array}{c}67 \\
39.0 \%\end{array}$ & $\begin{array}{c}69 \\
40.1 \%\end{array}$ & $\begin{array}{c}4 \\
2.3 \%\end{array}$ & $\begin{array}{c}2 . \\
1.2 \%\end{array}$ & $\begin{array}{c}2 \\
1.2 \%\end{array}$ & $\begin{array}{l}172 \\
100 \%\end{array}$ & $\begin{array}{l}172 \\
100 \%\end{array}$ \\
\hline
\end{tabular}

母子生活支援施設は、建物の老朽化 ${ }^{13}$ や居室の狭さ ${ }^{14} に$ 加え、施設 㑡が提供するサービスと利用者ニーズとの非離 ${ }^{15}$ 、更には、施設に 対する差別視の風潮等の問題 ${ }^{16}$ を车んでおり、これらの問題が利用 者数の低下 ${ }^{17}$ に繁がっているとしばしば指摘されている。

従って、これらの点が、母子生活支援施設に転居する世帯の割合 （2.3\%）の低さに反映されているのではないかと推測される。

公営住宅は、供給不足・地域的偏在の問題に加え、応㐞時期が決 まっていることや、忘募から入居まで時間がかかること等の条件 ${ }^{18}$
があるため、住宅の確保に急を要する母子世帯にとうては利用が困 難になっているのが現状である。

そのため、住宅確保の準備が不十分であると推測される、「母子 世帯になる前」や「母子世带になると同時に転居」した世帯では、 その多くが親類・知人宅に身を寄せるなどして住宅確保の問題を回 避しているのである。また、頼る親類・知人がいない、あるいは親 類・知人に頼ることを希望しない世帯は、経済状況が不安定であっ ても、さしあたり入居可能な民間借家に依存せざるを得ない。

他方で、母子世帯になってからしばらくして転居する世帯に関し ては、住宅確保に十分な準備期間が持てるため、公営住宅への入居 が可能になる世帯も多くなるのである。

\section{4-2. 居先と居住期间}

ここでは、転居した 172 世帯の転居先とそこでの居住期間につい て分析する (表 11)。

持家、公営住宅及び公団・公社住宅に転居した世帯は、その住宅 に「今も住んでいる」とする割合が 100\%であり、1回の転居でそ こに定住する可能性が極めて高い。一方、民間借家および親類・知 人宅に身を寄せた世帯では、継続して住んでいる割合は、民借 $47.8 \%$ 、親類・知人宅 $50.7 \%$ と持家・公共住宅の半分程度であった。

また、民間借家に転居した世帯の $20.9 \%$ 、親類知人宅に転居し た世帯の $30.3 \%$ が 1 年以内にそこを転居している。

こうした事実から、民間借家および親類・知人宅へ転居した世帯 は、不安定居住を強いられていることがわかる。

転居先によって居住の継繶期間に差異が生じるの惊、親類・知人 宅では、1) 同居人に気兼ねをするなと゚、そこに居辛くなることや、 2)そこが仮住まいの場となっている点が挙げられる。

民間借家では、1）さしあたり入居した住宅がニーズを満たすも のでない場合や、2)家貨負担に耐えられなくなることが要因ではな いかと考えられる。

产 11 居先と居住期间（不明 2 件を亚く（P<0. 001）

\begin{tabular}{|c|c|c|c|c|c|c|c|}
\hline & \multicolumn{5}{|c|}{ 酛居した住宅に居住していた期間 } & \multirow[b]{2}{*}{ 合偖 } \\
\hline & & ーヶ月 & 半年 & 一年 & 一年以上 & $\begin{array}{l}\text { 今もも住ん } \\
\text { でいる }\end{array}$ & \\
\hline \multirow{7}{*}{$\begin{array}{l}\text { 完 } \\
\text { 居 } \\
\text { 先 }\end{array}$} & 持永 & $\begin{array}{c}0 \\
0 \%\end{array}$ & $\begin{array}{l}0 \\
0 \%\end{array}$ & $\begin{array}{l}0 \\
0 \%\end{array}$ & $\begin{array}{c}0 \\
0 \%\end{array}$ & $\begin{array}{c}12 \\
100 \%\end{array}$ & $\begin{array}{c}12 \\
100 \%\end{array}$ \\
\hline & 公営住宅 & $\begin{array}{c}0 \\
0 \%\end{array}$ & $\begin{array}{c}0 \\
0 \%\end{array}$ & $\begin{array}{l}0 \\
0 \%\end{array}$ & $\begin{array}{c}0 \\
0 \%\end{array}$ & $\begin{array}{c}14 \\
100 \%\end{array}$ & $\begin{array}{c}14 \\
100 \%\end{array}$ \\
\hline & 公団·公社 & $\begin{array}{c}0 \% \\
0 \%\end{array}$ & $0 \%$ & $\begin{array}{l}0 \\
0 \%\end{array}$ & $\begin{array}{l}0 \\
0 \%\end{array}$ & $\begin{array}{c}2 \\
100 \%\end{array}$ & $\begin{array}{c}2 \\
100 \%\end{array}$ \\
\hline & 民間措家 & $\begin{array}{c}0 \\
0.0 \%\end{array}$ & $\begin{array}{c}6 \\
8.6 \%\end{array}$ & $\begin{array}{c}8 \\
11.4 \%\end{array}$ & $\begin{array}{c}22 \\
31.4 \%\end{array}$ & $\begin{array}{c}34 \\
48.6 \%\end{array}$ & $\begin{array}{c}70 \\
100 \%\end{array}$ \\
\hline & 周居 & $\begin{array}{c}3 \\
4.3 \%\end{array}$ & $\begin{array}{c}11 \\
15.9 \%\end{array}$ & $\begin{array}{c}7 \\
10.1 \%\end{array}$ & $\begin{array}{c}13 \\
18.8 \%\end{array}$ & $\begin{array}{c}35 \\
50.7 \%\end{array}$ & $\begin{array}{c}69 \\
100 \%\end{array}$ \\
\hline & その他 & $\begin{array}{c}0 \\
0.0 \%\end{array}$ & $\begin{array}{c}1 \\
16.7 \%\end{array}$ & $\begin{array}{c}1 \\
16.7 \%\end{array}$ & $\begin{array}{c}2 \\
33.3 \%\end{array}$ & $\begin{array}{c}2 \\
33.3 \%\end{array}$ & $\begin{array}{c}6 \\
100 \%\end{array}$ \\
\hline & 合㖕 & $\begin{array}{c}3 \\
1.7 \%\end{array}$ & $\begin{array}{c}18 \\
10.4 \%\end{array}$ & $\begin{array}{c}16 \\
9.2 \%\end{array}$ & $\begin{array}{c}37 \\
21.4 \%\end{array}$ & $\begin{array}{c}99 \\
57.2 \%\end{array}$ & $\begin{array}{c}173 \\
100 \%\end{array}$ \\
\hline
\end{tabular}

\section{5. 枟居に際する困嚾}

転居に際する困難の有無と困難があると回答した世帯の困難の 内訳を表 12 に示す。

転居に䟢して困ったことがあったと回答した世帯は72.4\%であり、 特に困ったことがなかったと回答した世帯は、27.6\%であった。 


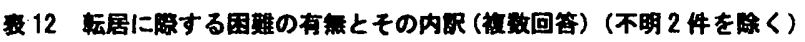

\begin{tabular}{|c|c|c|c|c|c|c|c|c|c|}
\hline & \multirow{2}{*}{\multicolumn{2}{|c|}{ 困峣なし 困斟あり }} & \multicolumn{5}{|c|}{ 困篗ありと回客した世带の因教の内訳 } & \multirow{2}{*}{$\begin{array}{c}\text { 有勃回 } \\
\text { 管数 }\end{array}$} \\
\hline & & & & \multirow{2}{*}{\begin{tabular}{|c|} 
入居拒否 \\
0
\end{tabular}} & \multirow{2}{*}{$\frac{\underbrace{\text { 䃂保 }}_{\text {保人の }}}{0}$} & \multirow{2}{*}{  } & \multirow{3}{*}{ 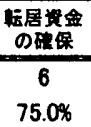 } & \multirow{3}{*}{ 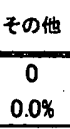 } & \\
\hline \multirow{10}{*}{$\begin{array}{l}\text { 㼮 } \\
\text { 先 }\end{array}$} & & 4 & 8 & & & & & & 12 \\
\hline & & $33.3 \%$ & $66.7 \%$ & $0.0 \%$ & $0.0 \%$ & $75.0 \%$ & & & \\
\hline & \multirow{2}{*}{ 共住宅 } & 5 & 11 & 0 & 1 & 7 & 6 & 0 & 16 \\
\hline & & $31.3 \%$ & $68.8 \%$ & $0.0 \%$ & $9.1 \%$ & $63.6 \%$ & $54.5 \%$ & $0.0 \%$ & \\
\hline & \multirow{2}{*}{ 民成借菑 } & 6 & 61 & 15 & 12 & 20 & 48 & 3 & 67 \\
\hline & & $9.0 \%$ & $91.0 \%$ & $24.6 \%$ & $19.7 \%$ & $32.8 \%$ & $78.7 \%$ & $4.9 \%$ & \\
\hline & \multirow{2}{*}{  } & 30 & 39 & 4 & 9 & 18 & 22 & 4 & 69 \\
\hline & & $43.5 \%$ & $56.5 \%$ & $10.3 \%$ & $23.1 \%$ & $48.7 \%$ & $56.4 \%$ & $10.3 \%$ & \\
\hline & \multirow{2}{*}{ その他 } & 2 & 4 & 0 & 0 & 4 & 1 & 1 & 6 \\
\hline & & $33.3 \%$ & $66.7 \%$ & $0.0 \%$ & $0.0 \%$ & $100.0 \%$ & $25.0 \%$ & $25.0 \%$ & \\
\hline \multicolumn{2}{|r|}{ 全体 } & $\begin{array}{c}47 \\
27.6 \%\end{array}$ & $\begin{array}{c}123 \\
72.4 \%\end{array}$ & $\begin{array}{c}19 \\
15.4 \%\end{array}$ & $\begin{array}{c}22 \\
17.9 \%\end{array}$ & $\begin{array}{c}57 \\
46.3 \%\end{array}$ & $\begin{array}{c}83 \\
67.5 \%\end{array}$ & $\begin{array}{c}10 \\
8.1 \%\end{array}$ & 170 \\
\hline
\end{tabular}

泩）公共住宅には、公客住宅（14 件）と公团・公社住宅（2 牛）が含まれている。

住宅所有関係別では、「困難あり」が、民間借家で $91.0 \%$ と特に 高い割合を示している。逆に、「困難なし」の割合は親類・知人宅 に転居した世带において高くなっている。

転居に䟢して困った問題について特に回答が多かったのは「転居 資金の確保が難しかった」が 67.5\%、繶いて「子供を転校させた」 が $46.3 \%$ であった。

「転居資金の確保」については、母子世帯の生活状況 ${ }^{19}$ を考慮する と、いずれの住宅に転居する世帯にとっても困難であると考えられ るが、特に、民間借家においてその割合 $(78.7 \%)$ が高くなってい る。民間借家は、家貨が高額であることは勿論だが、敷金等の一時 金支払いは極めて負担が重い。そのため、さしあたり貯蓄を取り崩 すか、親類・知人等から借金をするなどして急場をしのぐ世帯も少 なからず存在するのではないかと考えられる。

「子供を転校させた」については、両親の離婚や父親との死別に よって生活環境が変化する上に学校まで転校することは、子供にと って大きなストレスになると考えられる。

同じ学区内で住宅を探し、この問題をなんとか回避したいと考え るのは当然のことであるが、家貨の問題も含めて障害は多い。

比較的入居しやすい公共住宅は郊外の不便な地域にあり、子供を 転校させずに入居できる世帯は限られている。そのため、公共住宅 に転居した世帯では「子供を転校させた」の割合 $(63.6 \%)$ が高く なっているのである。

他方で、民間借家に転居した世帯では、他の住宅に転居した世帯 と比較して「子供を転校させた」の割合（32.8\%）が低くなってい る。このことから、民閒借家は家穓が高積である等のデメリットは あるものの、立地をフレキシブルに選択できるという点では母子世 帯のニーズを満たすものになっているといえる。

「保証人確保」の問題や母子世帯であるが故に「入居拒否」され たという問題も、母子世帯が住宅を確保する上で大きな障害になる。

これらの回答は、民間借家や親類・知人宅に転居する世帯におい て多く見られる。親類・知人宅に転居した世帯では、現在でも、こ れらの問題を解決できず、そこに止まらざるを得ない状況になって いる。

\section{6. 結}

母子世帯の住宅確保は、子どもの環境を考虑しなければならない
という点で他の住宅弱者、例えば、滈齢者や障害者と問題が大きく 異なる。また、母子世带は、ひとり親という共通点を持つ父子世带 と比較すると、経済力が低いため ${ }^{20}$ 住宅確保もより一層困難である と考えられる。

更に、民閒借家や親類・知人宅に転居する世带の中には、保証人 確保の問題や家主や不動産業者からの差別視の問題に直面してい る世帯も存在し、それらが彼女達の住宅確保を更に困難なものにし ていた。

住宅確保が特に困難であるといえるのが、「母子世帯になる前」 や「母子世帯になった直後」に転居する世帯である。母子世帯にな った直後では、無業の割合が高いことや（図 1)、日本学働機構の調 查（2003）において、回答者の半数以上が「母子世帯になって経済 的に苦しくなった」と回答していることから になっていると推測される。そのため、この時期に転居した世帯の 多くは、自活できずに親類・知人宅に仮住まいをする、あるいはさ しあたり入居可能な民間借家に依存せざるを得ない状況にある。

これらの結果から、母子世带の住宅確保は、一時非難期と安定し た住宅への移行期で異なった支摱が必要であるといえる。

一時避難期に対する対応としては、緊急一時保護事業22の拡充が 必要である。近年では、暴力（DV）被害者を対象とした民間シェ ルター ${ }^{23}$ が緊急避難所を積極的に提供している。母子生活支援施設 の中にも、緊急一時保護事業を実施しているものもあるが、まだま だその数は不足している ${ }^{24}$ 。今後、母子生活支援施設を緊急避難所 として積極的に活用していくことで、施設のサービスを母子世帯の ニーズに摺り奇せていくことが重要であろう。

続いて、安定した住宅への移行期つまり、安定した住宅を探す精 神的・䅅済的余裕が出てきた段階に対する対応としては、子育てや 就業が可能な地域で、支払い可能な家賃の住宅にアクセスできるよ うに支援していくことが必要である。そのためには、住居費の問題、 母子世带に対する家主や不動産業者からの差別視の問題、保証人問 題の解決が急務である。住居費の問題に関しては、一時金や家貨に 対する補助が必要であると考えられる。また、差別問題の解決に対 しては、母子世帯であることを理由に入居を拒否することのない賃 貸住宅を登録 ${ }^{25}$ し、その情報を広く提供していくことも有効な手段 の1つではないだろうか。最後に、保証人問題への対応についてで あるが、非営利組織の中には、保証人問題を抱える母子世帯に対し て保証人代行支援を行っているケースも見受けられる な支援を公的に広めていく必要があるだろう。

〈謝辞〉 本研究にあたっては、社会福祉法人大阪府母子塞婦福祉 連合会事務局長の足立久美子氏をはじめ会員の皆様からご協力い ただいた。ここに記し謝意を表する。

\section{<参考文献〉}

1）田端光美（1993）「女性の自立と社会保障」『女性の自立と居住保障』東京 大学出版会

2）杉本貴代栄（1997）『日本のシングルマザーたち』ミネルヴァ帮房

3）林千代（1992）『母子费の戦後史』ドメス出版

4）松原康雄（1999）『母子生活支援施設』エイテル研究所

5) 由井新道 (2000)『東京都におけるひとり親世帯の住宅問題』地理科学 55-2 地理科学学会

6）由井義道（2003）『家族類型別に見た住宅事情一母子世帯の住宅問題一』 統計第 54 巻第 6 号財団法人日本統計協会

7）湯沢直美（1997）「社会福祉のなかのジェンダー」『母子原と女性問題』ミ 
ネルヴァ書屏

8）（2000）『全国母子世帯等部査の概要』厚生省児童家庭局

9）（2002）『平成 14 年社会福祉施設等堣查』厚生省大臣官房統計情報部

10）（1997）『離婚家庭のこども』厚生省大臣官房統計情報部

11）（1996）『京都府母子・父子世带実態調查結果報告害』京都府保健福祉部 罗童保健福祉餜



13）（1997）『福岡目母子世帯等実態葫查結果報告害』福岡県民生部

14）(2001）『熊本県母子世帯等実態調查結果報告書』熊本県揵康福祉部

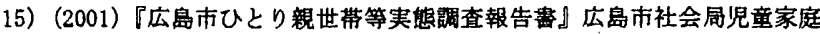

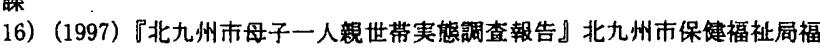
祉部児童家庭既

17）（1997）『福岡市母子世帯等実態調查報告婁』福岡市民生局

18）（2004）『大阪市ひとり親家庭実態調查結果の概要』大阪市健康福社周

19）（2003）『母子世帯の母人の就業支援に関する研究』日本労働研究機權

〈注〉

1997 年の厚生省大臣官房統計情報部『雄婚家庭の子供』によると、調查 対象世帯 1,544 世帯のうち、離婚を機に転居したとする割合は $66.6 \%$ であ った。その他、母子世帯になってからの転居の状況が把握できる調查には、 京都府 $(n=4546)$ 、和歌山県 $(n=1402)$ 、福棡県 $(n=1717)$ 、熊本県 $(n=1178)$ 、 広岛市 $(n=764) 、$ 北九州市 $(n=1434)$ 、福岡市 $(n=1300)$ の実態調查がある。 その結果を見ると、母子世带になることを機に転居する割合は、京都府 $(44.7 \%)$ 、和跑山県 $(56.2 \%)$ 、福岡県 $(63.1 \%)$ 、熊本県 $(64.9 \%)$ 、広 岛市 $(59.2 \%) 、$ 北九州市 $(68.2 \%) 、$ 楅雕市 $(65.5 \%)$ であった。


保護施設である。この施設は、児重福祉法第38 条に位置つけけられてる。 社会福祉施設等調查によると、2002 年度におうける施設数は全国で 285 ヶ所 となっている。

公学住宅の優先入居制度は、公学住宅入居申込者のうち、一部住宅困宊度 の高い者を、一般住宅因穿者よりも優先して住宅の援助を行うというもの であり、通達に基づいて夷施されている。1955 年に、はじめて、公営住宅 入居者選考の際に母子世帯を優先的に取り扱う旨の通達が出されてから、 数度の通達を経て現在に至っている。

母子福祉资金は、母子及び家婦福祉法第 10 条に位置つけられる贷付事柴で ある。その中で住宅に関する贷付事業は、住宅資金及び転宅資金である。 住宅資金と怯、現在住んでいる住宅の増改第や補修に必要な瓷金、又は自 ら居住する住宅の建設及び睓入するために必要な资金の貸付事業である。 転宅資金とは、住居の移転に伴う敷金、権利金などの一時金に充てる資金 である。

3.由端は、1990年の国勢調查を利用し東京都のみの特徽をのべている。杉本 は、1993 年の名古屋市母子・父子世帯等生活実態睭查を利用している。由井 は 2000 年の国勢泪查を利用し、全国と関東地方（東京都、特別区、茨城県、 疗木県、群馬県、埼玉罢、千葉県、神奈川県、横浜市) の地域特性を分析し ている。また、1998 年の住究・土地統計锶査を利男し、「ひより親世带」の 特徴を述べている。

4昭和 25 年、母子世帇及び赛婦の楅被の増進を図ることを目的として設立さ れ、大阪府下 37 市郡の単位会て組織されている。事業内容は、大阪府加らの 委託事業である「母子家庭等就業・自立支援センター事業」として、各種就

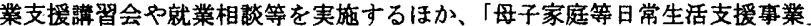
として、家庭生活支援員の派遗を行うなど、母子家庭の自立を幅広く支援し ている。これらの他、独自事業として、無料職業紹介所の開設、各種交流事 業、研修事業、子育て支援加ある。母子带会員は 4,600世帯であり、大阪 府の母世帯の約 7\%を占める。会員は主に大阪府下 37 市郡の役所で配布さ れている広報を見て入会してくる不特定多数の母子世帯が主体となっており その特徽に特別俯りがあるとは考えがたい。しかし、自発的に入会してくる という点で積極性があると考えられる。

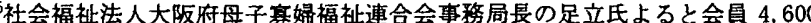
世带の大多数が生別母子世帯である。この情報は今回の調盉結果（生別・ $84.5 \%$ ) と概ね対応していると等える。

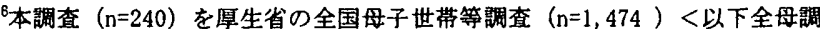
とする>を、(1)死別・生別割合、(2)年齢、(3)就策状況の 3 点から比較すると 以下の上うな結果になった。(1)本調査の死別・生別の割合はそれぞれ 15.4\%、 84.6\%であり、全母䀦のそれ（死別・18.7\% 生別・79.9\%) とほぼ同様の傾 向を示している。(2)年齢階層を見ると、本調查では、30 代 (55.8\%)、40 代 (36.7\%)の㓶合が高い。これに対して全母調では、40 代 (42.6\%)、30 代 (28.1\%) の割合が高い。(3)本調查の無業 (16.3\%)、有業 (83.8\%) の割合は全母調のそ

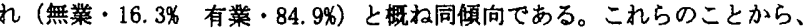
本調查は、全母路と比較すると、年龄階層が若干若くなっているが、生別・ 死別の割合及び就業状況劃合はほぼ同傾向を示していると言える。

7 本アンクート調查自由部述墛による。

${ }^{8}$ 大阪市ひとり親家庭実態調查結果の概要によると、回答者 1,182 人のうち 持家に居住しているのは $18.2 \%$ (215人) であり、その $31.6 \%$ が住宅ローン
の返済を困難であると回答している。このことから、転居の理由として、 住宅ローン負担があったと十分に推測される。

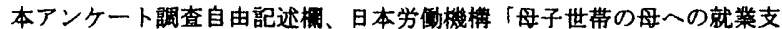
援に関する研究」(2003) p66 自由婄述杼から母子世帯になることで親や兄 弟・姉妹との関係が墨くなり実家にいつららくなるという実態が見て取れる。 ${ }^{10}$ 大阪市ひとり親家庭実態調查結果の概要によると、母子世帯であるとい うことで差別や偏見を受けた体臥がある世帯は、全回答者 1,182 人中 436 人 (36.9\%) である。どのような場面で差別や偏見を感じたかという問に 対しては、「となり近所のうわさ」が最も多く $54.5 \%$ となっている。これ らのことから、近隣の目が転居理由の1つとして举げられるのではないか と考えられる。

11 本アンケート謂査の調查時点における住居费は、公営住宅 (21、329 円)、 民間借家 $(58,391$ 円）である。また住居费負担率は公営住宅（13.0\%）、民 間借家 $(47.4 \%)$ である。

${ }^{12}$ 本アンケート調查自由記述桐及び筆者のヒアリング調查による。近年、DV を理由とする母子世帯数の増加が社会問题視されている。母子世帯の住宅事 情は、母子世帯になった理由によって異なると考えられ、中でも DV を理由と する母子世帯の住宅確保は一層困難であると推測される。本娚查からは、母 子世帯になった理由と住宅事情の相違という点についてまで路み込んで晋及 できないが、この点については重要であると考えられるため、今後の研究眯 題としたい。

${ }^{13}$ 松原（1999）の調查によると、調查対象世带（769 世帯）のうち49\%が建物 や設備の老朽化に不渵を感じている。また、「ゴキブリやねずみが出る」「力 ビが生える」など衛生面の問題に不満を感じている世帯も多い

筆者のヒアリング調查による。施設の最低居案面㮴は 1 人あたり $3.3 \mathrm{~m}^{2}$ たあ り、子どもの数、性別、年齢に関わらず、1 家族に同じタイプの居室を与え ている施設がほとんどである。

${ }^{15}$ 松原（1999）の調查を見ると、特に、規則 $(50 \%) 、$ 薮内トラブル $(44 \%) 、$ 共同生活 (38\%) に不満を感じている世帯の割合が高い。

${ }^{18}$ 田端（1993）は1970年代頃から利用者数が低下した要因として施設に対す る差別梘の風潮を指摘している。

171964 年に全国に 629 ヶ所あった施設が、2002 年には 285 ヶ所にまで城少し ている。

18调查対象地区である大阪府住宅管理橦に対するヒアリングによると，符営住 宅の募集には、1）䌊合募集、2）あき屋待ち募集、3）住宅因身度評定 集がある。

1）総合真集とは、新築及びあき家住宅を一般世帯向け（新筑・あき家）、新 婚世帯向け（あき家）、福祉世帯向け（新築・あき家）、親子近居向け及び高 齢者向け改善住宅の応募区分を設けて同時に応募を行うものである。応萝時 期は 5 月と 1 月の年 2 回である。応募から入居まで、約 5 ケ月を要する。 2) あき家待ち特別募集とは、大幅な㐞集割れが予想される特定の住宅に 限り、今後発生が予想されるあき家の入居予定者を無抽選で申し込受付覑 にあらかじめ登緑しておくものである。応莺は年に4回あり、申請から入 居までの期間は、最短でも約 3 ヶ月となっている。

3）住宅困籍度評定募集は、抽選ではなく、現在住んでいる住宅の状況（過 密狭小など）を点数化し、その合計点の高い順に当選者を選定するというも のである。各申し込み区分の募集戸数に合わせて点数の高い世帯から順に住 宅を赫旋するというものであり、攧位によっては、入居不可能な場合も方る。 ${ }^{18}$ 本調查では、母子世带になる前と後の経浲状洗について調查していないた め、母子世帯になることによってとの程度収入が低下したかについてまで夏 及できないが、日本労働機構の「母子带の母人の就業支援に関する研究」 （p456 表 5-17 意識）によると、回答者 1,721 人のうち、54.6\%が「母子世 带になって経済的に不安定になったと思う」と回答している。このことから 母子世帯になることによって生活が不安定になる状況が見て取れる。

${ }^{20}$ 平成 10 年全国母子世带等調查によると、母子世帯の平均年收は 229 万円で あり、父子世带の平均年収 422 万円の約 2 分の 1 程度となっている。 21 注 19 照。

${ }^{22}$ 地域社会での生活において、家族や個人が何らかの理由で危機的な状況に置 かれ生活遂行が困難になった際に、家財や日用品を備えた居室を提供し、生 命の安全と共に心身の瘟しと課題の解決に向けた支援を提供する機能である。 (松原 1996 p89)

${ }^{23} 2003$ 年 4 月時点の内閣府の発表によると、全国に 55 ヶ所存在する。

24 松原 (1996) p91

${ }^{25}$ 平成 13 年 10 月 1 日「高龄者の居住の安定確保に関する法律」が施行された。

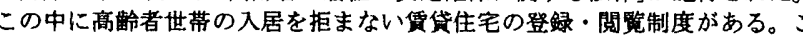
れは、高歯であるがために民間便贷住宅市場から排除されがちな高齢者の住 宅確保を支援するためのもので、高龄者であることを理由に入居を拒否する ことのない霓袋住宅を登録し、その情報を広く提供するというものである。 これは、母子世帯であるという理由で民間货貸住宅市場から排除されがちな 母子世帯に対しても有効な制度であると考えられる。

${ }^{26}$ 東京都内において一人親家庭に対する支援を行っている非営利組織 Wink は 2003 年 3 月から赁贷物件を保有している企業と提拹し母子世帯に対する保証 人代行支援を行っている。現在は神奈川県内の物件が対象となっている。

(2004年6月10日原稿受理，2004年10月28日採用決定） 